\title{
Evaluasi Media Ajar AR Halo Kids Pada Anak Dengan Teknologi Augmented Reality Berbasis Android
}

\author{
Fendi Aji Purnomo \\ Fakultas MIPA, Program Studi D3 Teknik Informatika \\ Universitas Sebelas Maret \\ Email: fendi_aji@mipa.uns.ac.id
}

\author{
Eko Harry Pratisto, Firma Sahrul Bahtiar, Muh. 'Adli Zul Hazmi \\ Fakultas MIPA, Program Studi D3 Teknik Informatika \\ Universitas Sebelas Maret \\ eko.harry@gmail.com, firma.sb@gmail.com, adlisinatra@gmail.com
}

\begin{abstract}
ABSTRAK
Penelitian ini bertujuan sebagai media pembelajaran yang mudah dan murah yang dapat digunakan untuk menambah edukasi bagi anak usia dini seperti pengetahuan mengenai pengenalan berbagai macam profesi. Media belajar berupa fisik pada saat ini dinilai cukup mahal, selain itu media belajar berupa fisik perlu pemahaman yang lebih untuk dapat memahami sesuatu yang dipelajari.

Penelitian ini dikembangkan dengan metode SDLC (System Development Life Cycle). Penelitian ini termasuk jenis pengembangan teknologi augmented reality yang berisi tentang wawasan mengenai berbagai macam profesi, tanaman, alat musik, dan kebutuhanku. Objek yang diambil tentang karakter profesi, bentuk alat musik, bentuk tanaman, dan bentuk peralatan rumah tangga. Teknik pengumpulan data dilakukan dengan angket. Angket ini digunakan untuk menilai kelengkapan serta kelayakan aplikasi. Software engine yang digunakan adalah unity game engine.

Hasil dari penelitian telah berhasil diciptakan aplikasi HALO KIDS berupa gambaran visual 3D tentang beberapa tema diantaranya profesi, kebutuhanku, alat musik, dan tanaman. Aplikasi HALO KIDS merupakan file dengan ekstensi .apk. Aplikasi HALO KIDS dijalankan secara optimal dengan ponsel pintar minimal berspesifikasi perangkat Quad-core $2.3 \mathrm{GHz}$ (2 GB RAM). Penggunaan aplikasi oleh anak-anak mudah dilakukan dengan nilai Setuju-Sangat Setuju sebesar $59 \%$, objek 3D profesi dapat dikenali dan diingat oleh anak dengan nilai setuju-sangat setuju sebesar $67 \%$.
\end{abstract}

Kata kunci: Augmented Reality, Media Ajar, Anak, Android.

\section{ABSTRACT}

This study aims as an easy and inexpensive learning media that can be used to increase education for early childhood such as knowledge about the introduction of various professions. Media learning in the form of physical at this time is considered quite expensive, in addition to learning media in the form of physical need more understanding to be able to understand something learned.

This research was developed with SDLC (System Development Life Cycle) method. This research includes the kind of augmented reality technology development that contains insight into the various professions, plants, musical instruments, and my needs. Objects taken about the character of the profession, the form of musical instruments, the shape of the plant, and the form of home appliances. Data collection techniques were conducted by questionnaire. Questionnaire is used to assess the completeness and feasibility of the application. Software engine that we use is unity game engine.

The results of the research has been successfully created HALO KIDS applications in the form of $3 D$ visual images of several themes including professions, needs, instruments, and plants. The HALO KIDS app is a file with a apk extension. The HALO 
KIDS app runs optimally with a minimal smartphone specifying a $2.3 \mathrm{GHz}$ Quad-core device (2 GB of RAM). The use of applications by children is easy to do with Agree-Strongly Agree value of 59\%, 3D objects of the profession can be recognized and remembered by children with the value of agree- strongly agree at $67 \%$.

Keywords: Augmented Reality, learning tool, Kids, Android.

\section{PENDAHULUAN}

Pendidikan anak usia dini (PAUD) \& TK adalah jenjang pendidikan sebelum jenjang pendidikan dasar yang merupakan suatu upaya pembinaan yang ditujukan bagi anak sejak lahir sampai dengan usia enam tahun yang dilakukan melalui pemberian rangsangan pendidikan untuk membantu pertumbuhan dan perkembangan jasmani dan rohani agar anak memiliki kesiapan dalam memasuki pendidikan lebih lanjut. Usia anak sejak lahir sampai usia enam tahun merupakan masa emas perkembangan (golden age). Pada masa itu terjadi lonjokan luar biasa pada perkembangan anak yang tidak terjadi pada periode berikutnya. Media belajar berupa Komputer memiliki dampak bagi anak ketika komputer memberikan pengalaman konkret, anakanak bebas menggunakan dan mengontrol pengalaman belajar tersebut, anak dan guru belajar bersama, guru mendorong pengajaran teman sebaya dan guru menggunakan komputer untuk mengajarkan gagasan-gagasan yang sangat kuat. Banyak penelitian yang menunjukkan bahwa komputer memiliki manfaat bagi pengembangan potensi anak usia dini.

Teknologi Augmented Reality dapat menggabungkan interaksi antara objek real dan objek virtual. Media pembelajaran yang telah kami kembangkan untuk anak salah satunya yaitu pengenalan profesi pada anak. Aplikasi tersebut telah diupload melalui playstore dan dapat diujicobakan. Media ajar pengenalan profesi pada anak diperlihatkan pada Gambar 1.

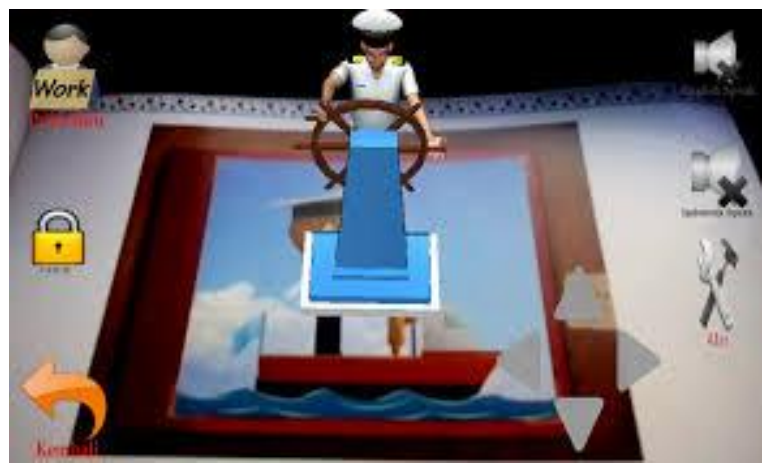

Gambar 1. Contoh media ajar interaktif pengenalan profesi nahkoda yang dikemas menggunakan teknologi Augmented Reality[5]

Berdasarkan penelitian yang dilakukan oleh Nubia [1] yang berjudul Development of a Mobile Application in Augmented Reality to Improve the Communication Field of Autistic Children at a Neurorehabilitar Clinic bahwa pengemasan bahan ajar menggunakan teknologi augmented reality memberi dampak pemahaman pengetahuan bahasa verbal terhadap anak sebesar $9 \%$ lebih baik dibanding pembelajaran secara konvensional. Seperti pernyataan oleh Poonsri [2] dalam penelitian yang berjudul Augmented Reality 3D Pop-up Children Book: Instructional Design for Hybrid Learning bahwa penggunaan Augmented Reality dalam pembelajaran hybrid memberikan pengalaman baru dalam pembelajaran dan efektif dalam penyampaian materi ajar. Diperkuat pula penelitian yang dilakukan oleh Pedro [3] yang berjudul Augmented reality for cognitive and social skills improvement in children with $A S D$ bahwa GameBook yang dikembangkan dengan teknologi Augmented Reality terbukti dapat meningkatkan aktivitas belajar bagi anak baik 
kemampuan mengingat, kemampuan kognitif dan social serta membantu anak dalam mengekspresikan emosi. Peneliti Nur Afiqoh [4] juga telah menawarkan alternatif pembelajaran pengenalan tanda keselamatan di sekolah dasar menggunakan teknologi multimedia, AR dan VR, hal ini dilakukan lantaran mahalnya alat peraga keselamatan dan masih konvensional.

Penelitian yang dilakukan oleh Sukma [5] dari Surakarta, berjudul Aplikasi "ARMengenal Profesi Pekerjaan" sebagai media pembelajaran mengenal profesi berbasis augmented reality pada perangkat mobile android. Penelitian ini membahas tentang macam-macam profesi yang di virtualkan. Informasi tentang profesi di buat secara virtual dalam bentuk 3 dimensi hanya terbatas dan berjumlah 6 profesi saja sehingga belum lengkap. Dalam penelitian ini akan dikembangkan dan diperluas lagi tema pembelajaran untuk anak yaitu meliputi pengenalan bertemakan profesi, pengenalan bertemakan kebutuhanku, pengenalan bertemakan tanaman dan pengenalan bertemakan alat musik. Fitur yang ditambahkan dalam penelitian ini adalah penambahan library konten pembelajaran secara 2D yang dapat dimainkan tanpa marker.

\section{METODOLOGI PENELITIAN}

Metode pengembangan aplikasi game yang digunakan adalah Software Development Life Cycle (SDLC) Water Fall dimulai dari analisis, perancangan, pembuatan, pengujian dan pemeliharaan.

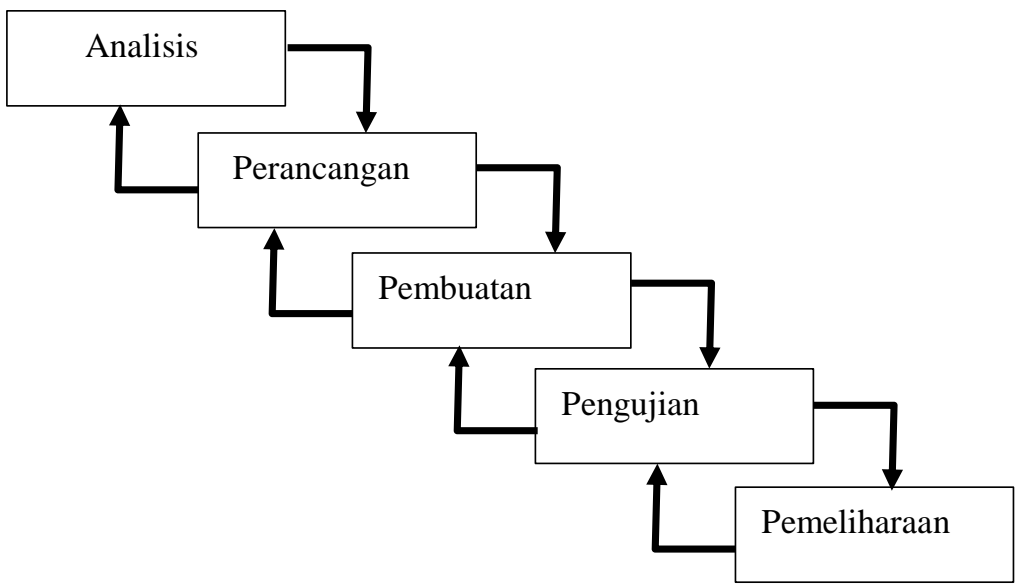

\section{Gambar 1. Metode Software Development Life Cycle (SDLC) Water Fall dalam pengembangan aplikasi games Petualangan Si Gembul}

\subsection{Tahap Analisis}

Analisis pada Gambar 1, tahap tersebut dilakukan melalui observasi langsung kemasyarakat dalam hal ini KB \& TPA Ayah Bunda di Colomadu, memiliki 23 murid dan 3 pengasuh. Observasi dilakukan terhadap permasalahan yang muncul selama pembeljaran berbasis tema diterapkan.

\subsection{Tahap Perancangan}

Dalam tahap perancangan pada Gambar 1, materi pembelajaran yangdikenalkan yaitu berbasiskan tema antara lain tema profesi, tema kebutuhanku, tema tanakan dan tema alat musik ditunjukkan pada Tabel 1. Terdapat 2 alternatfi pembelajaran yaitu pertama penggunaan aplikasi dibantu marker, hasil yang disajikan anak dapat melihat model 3D dan terdapat audio. Kedua apabila marker tidak ada aplikasi tetap dapat digunakan untuk pembelajaran, model ini hanya menyampaikan objek 2D saja. 
Kebutuhan Perangkat dalam Pembuatan AR HALO KIDS dibutuhkan computer dengan spesifikasi :Prosessor Intel corei3 1.50GHz, 4 GB RAM, 5 GB free hard drive. Kebutuhan perangkat dalam implementasi dan pengujian game yaitu : Android Jelly Bean or higher version, sedangkan spesifikasi hardware yang dibutuhkan yaitu :Smartphone Android, Dual Core or higher, dan variasi nilai RAM 1 GB, 2 GB, 3GB dan 4 GB. Sedang kebutuhan software yaitu Unity $3 D$ dan Vuforia untuk mengenali marker.

Tabel 1. Daftar objek pengenalan benda keseharian untuk dikemas dengan

Teknologi AR

\begin{tabular}{|c|c|c|c|}
\hline Tema Profesi & $\begin{array}{l}\text { Tema Kebutuhan } \\
\text { ku }\end{array}$ & $\begin{array}{l}\text { Tema buah dan } \\
\text { Sayur }\end{array}$ & Tema alat musik \\
\hline $\begin{array}{l}\text { a.Arsitek } \\
\text { b.Bidan } \\
\text { c.Tukang cukur } \\
\text { d.Dokter } \\
\text { e.Penari } \\
\text { f.Fotografer } \\
\text { g.Guru } \\
\text { h.Hakim } \\
\text { i.llmuan } \\
\text { j.Juru parkir } \\
\text { k.Koki } \\
\text { I.Penulis } \\
\text { m.Masinis } \\
\text { n.Nelayan } \\
\text { o.Tukang pos } \\
\text { p.Petani } \\
\text { q.nahkoda } \\
\text { r.Resepsionis } \\
\text { s.Satpam } \\
\text { t.Tentara } \\
\text { u.Ustad } \\
\text { v.Kameramen TV } \\
\text { w.Wasit } \\
\text { x.Supir taxi } \\
\text { y.Tukang kayu } \\
\text { z.pedagang }\end{array}$ & $\begin{array}{l}\text { Almari } \\
\text { Blender } \\
\text { Ceret } \\
\text { Dispenser } \\
\text { Ember } \\
\text { Figura } \\
\text { Gelas } \\
\text { Handuk } \\
\text { Jam } \\
\text { Kipas angin } \\
\text { Lampu Belajar } \\
\text { Magic com } \\
\text { Nampan } \\
\text { Oven } \\
\text { Payung } \\
\text { Rak buku } \\
\text { Sapu } \\
\text { Tv } \\
\text { Ulekan } \\
\text { Vas bunga } \\
\text { Wajan } \\
\text { miXer }\end{array}$ & $\begin{array}{l}\text { Apel } \\
\text { Belimbing } \\
\text { Cherry } \\
\text { Durian } \\
\text { Enau } \\
\text { Frambos } \\
\text { Halamba } \\
\text { Imbe } \\
\text { Jeruk } \\
\text { Kelapa } \\
\text { Lemon } \\
\text { Mangga } \\
\text { Nanas } \\
\text { Orange } \\
\text { Pisang } \\
\text { Rambutan } \\
\text { Strawberry } \\
\text { Tomat } \\
\text { Ubi } \\
\text { Waluh } \\
\text { Zaitun }\end{array}$ & $\begin{array}{l}\text { Angklung } \\
\text { Biola } \\
\text { Chimes } \\
\text { Drum } \\
\text { Kecapi } \\
\text { Flute } \\
\text { Gitar } \\
\text { Harmonika } \\
\text { Siter } \\
\text { Jingle bells } \\
\text { Ketipung } \\
\text { Suling } \\
\text { Marakas } \\
\text { Rebana } \\
\text { Gong } \\
\text { Piano } \\
\text { Rebab } \\
\text { Sanza } \\
\text { Tamborin } \\
\text { Bedug } \\
\text { Vibraphone } \\
\text { Cowbell } \\
\text { Saxophone } \\
\text { Cymbal } \\
\text { Kazoo }\end{array}$ \\
\hline
\end{tabular}

\subsection{Tahap Pembuatan}

Dalam penggunaanya, kamera ponsel didekatkan pada marker, lalu kamera membaca marker tersebut sebagai input data yang kemudian diproses oleh vuforia yang sudah terdapat pada aplikasi HALO KIDS. Apabila inputan sesuai dengan inisialisasi marker yang menjadi acuan dalam sistem yang telah dibuat, maka akan ditampilkan animasi simulasi profesi dalam bentuk objek 3D beserta informasi dan audionya. Dan apabila inputan tidak sesuai dengan inisialisasi marker yang menjadi acuan dalam sistem, maka proses akan kembali ke pembacaan marker melalui scan kamera atau tidak muncul objek 3D apapun. Adapun proses tersebut dapat dilihat pada Gambar 2. 


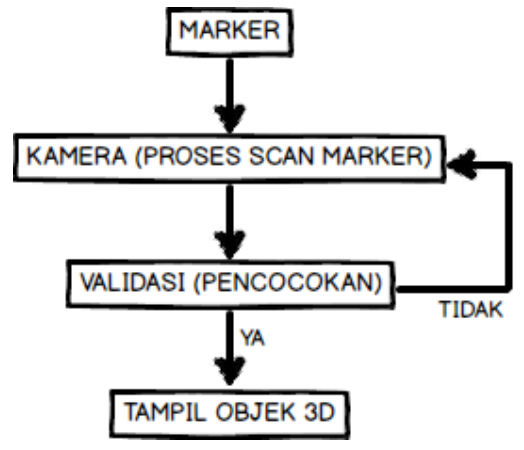

\section{Gambar 2. Alur Proses Pembacaan Marker}

Marker akan dideteksi sebagai image (gambar), yang kemudian dibaca oleh kamera masuk ke proses scan yang dilakukan oleh kamera ponsel.

\subsection{Tahap Pengujian}

Tahap pengujian pada Gambar 1, pengujian dalam game ini dilakukan melalui pengujian blackbox, pengujian game terhadap perangkat android dengan variasi RAM yang ditentukan, dan pengujian kemanfaatan game melalui kuisioner terhadap pengguna. Aspek yang dinilai melalui kuisioner yaitu tampilan aplikasi game dan aspek kemudahan informasi.

\subsection{Tahap Pemeliharaan}

Tahap pemeliharaan pada Gambar 1, pemeliharaan dilakukan melalui tahap release aplikasi AR-HALO KIDS versi 1 dan dipublikasi melalui website http://ar-halokids.com supaya mudah dalam update apabila terdapat pembaharuan aplikasi tersebut seperti ditunjukkan pada Gambar 1.

\section{HASIL DAN PEMBAHASAN}

Pembuatan marker dibuat dalam kartu yang unik dan lucu terdapat illustrasi gambar untuk masing-masing tema dan terdapat informasi nama sesuai objek gambar tersebut. Kartu katalog tersebut kemudian oleh Vuforia akan dikenali sebagai marker yang dapat digabungkan dengan objek virtual melalui Unity 3D. Sample kartu marker aplikasi AR HALO KIDs ditunjukkan pada Gambar 3.

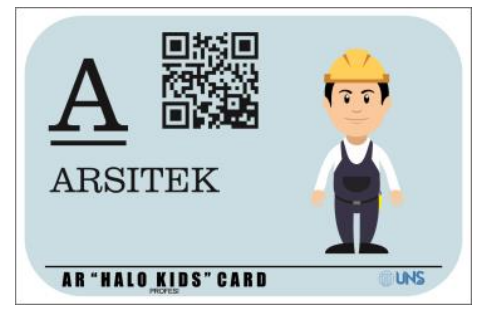

\section{Gambar 3. Karu sebagai marker aplikasi AR HALO KIDS}

Marker selanjutnya akan diinisiasi titik-titik penting melalui website vuforia.com. File yang dapat diterima website vuforia adalah.JPG dan .PNG dengan batas maksimal $2 \mathrm{mb}$. Kemudian pada kolom width diberikan input-an 300 di mana marker yang dihasilkan pada vuforia tidak terlalu kecil dan tidak terlalu besar. Pengenalan keterbacaan marker 
oleh aplikasi AR oleh Vuforia diindikasi dengan nilai rating bintang, semakin banyak ratingnya semakin mudah dikenali aplikasi AR, seperti ditunjukkan pada Gambar 4.

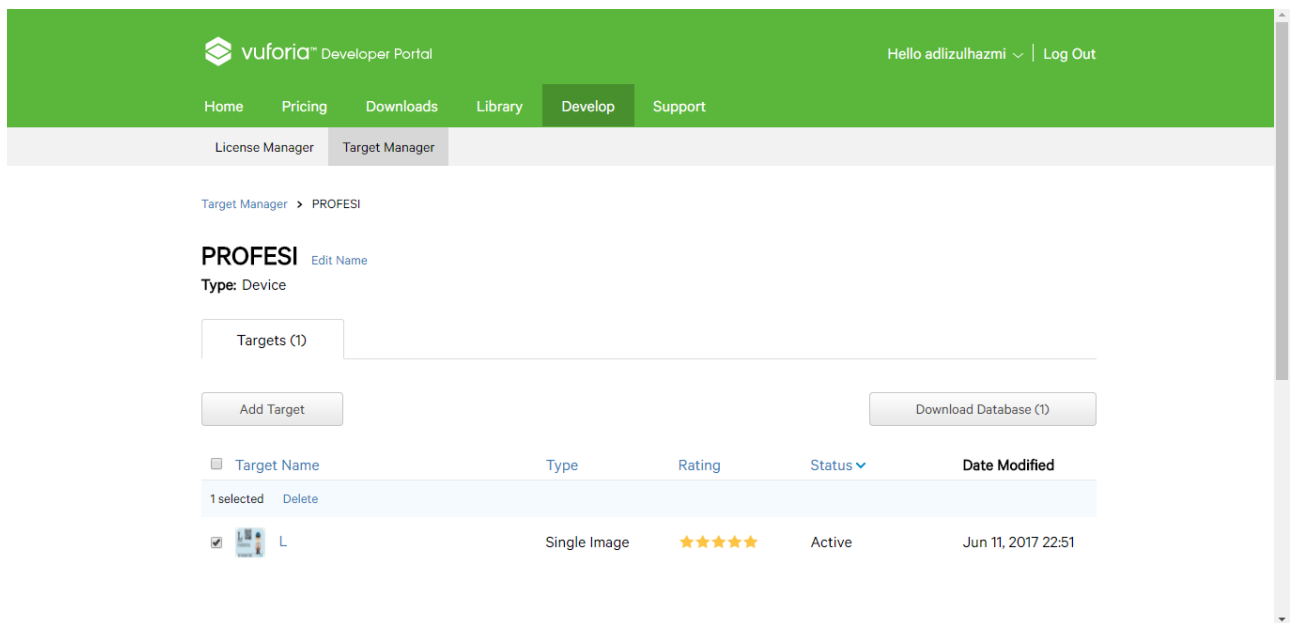

\section{Gambar 4. Tampilan Halaman Website Vuforia Setelah Upload Marker}

Pembuatan scene menu utama sama dengan pembuatan scene awal sebagai splash screen. Hanya saja pada scene menu ini ditambahkan dengan penempatan tombol yang memiliki fungsi yang berbeda- beda. Buat script dengan klik kanan pada window project. Kemudian import icon tombol dengan cara men drag icon tersebut kedalam unity. Atur texture type menjadi GUI dan Sprite 2D pada window inspector agar gambar yang ditampilkan tidak terlihat pecah. Berikut tampilan main menu dapat dilihat pada Gambar 5.

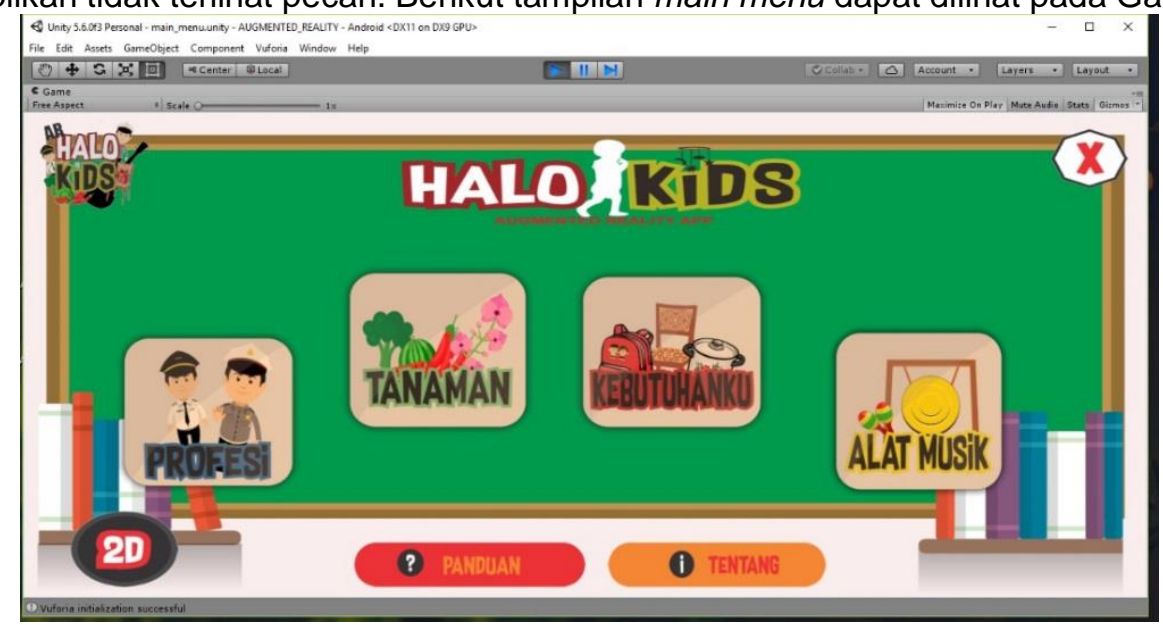

\section{Gambar 5. Main Menu Utama lengkap dengan tema pembelajaran}

Menu play atau game play merupakan menu setelah menu utama, atau menu inti dari aplikasi. Menu ini didalamnya terdapat proses scanning marker yang kemudian akan tampil objek 3D. Pada menu ini juga terdapat ulasan mengenai informasi objek 3D yang ditampilkan. Selain itu, terdapat tombol (button) pengaturan on atau off audio, dan tombol kembali. Tampilan dapat dilihat pada Gambar 6 . 


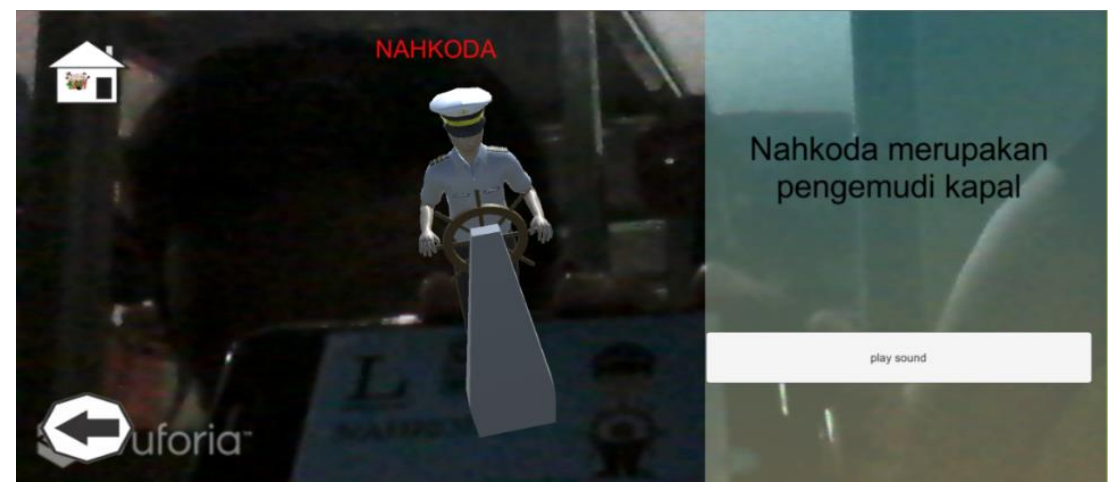

Gambar 6. Tampilan Menu Play atau Game Play

Tampilan menu panduan digunakan untuk menunjukkan untuk menampilkan informasi mengenai cara penggunaan aplikasi AR HALO KIDS. Gambar menu panduan dapat dilihat pada Gambar 7.

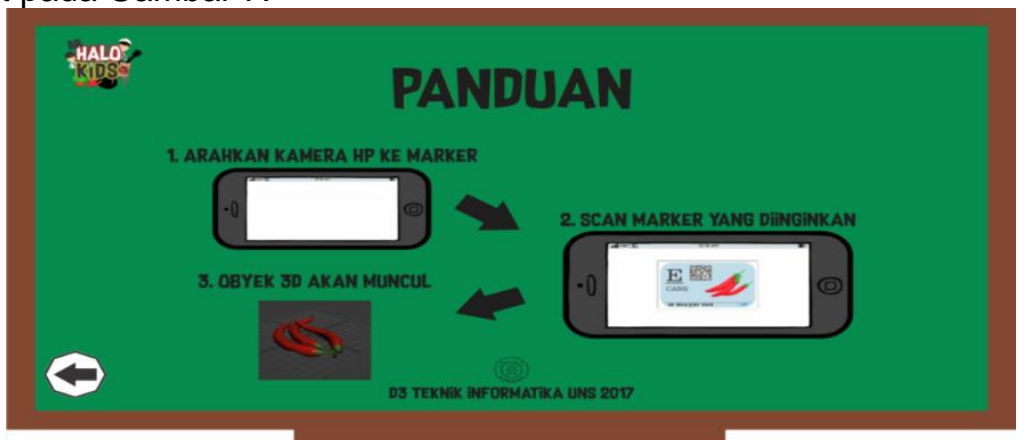

Gambar 7 Tampilan Menu Panduan Apliakasi AR HALO KIDS

Tampilan menu 2D merupakan library aplikasi HALO KIDS. Di mana semua objek pembelajaran disajikan dengan versi objek 2 dimensi. Hal ini dimaksudkan apabila marker aplikasi tidak tersedia pembelajaran tetap dapat berlangsung. Tampilan menu 2D dapat dilihat pada Gambar 8 dan Gambar 9.

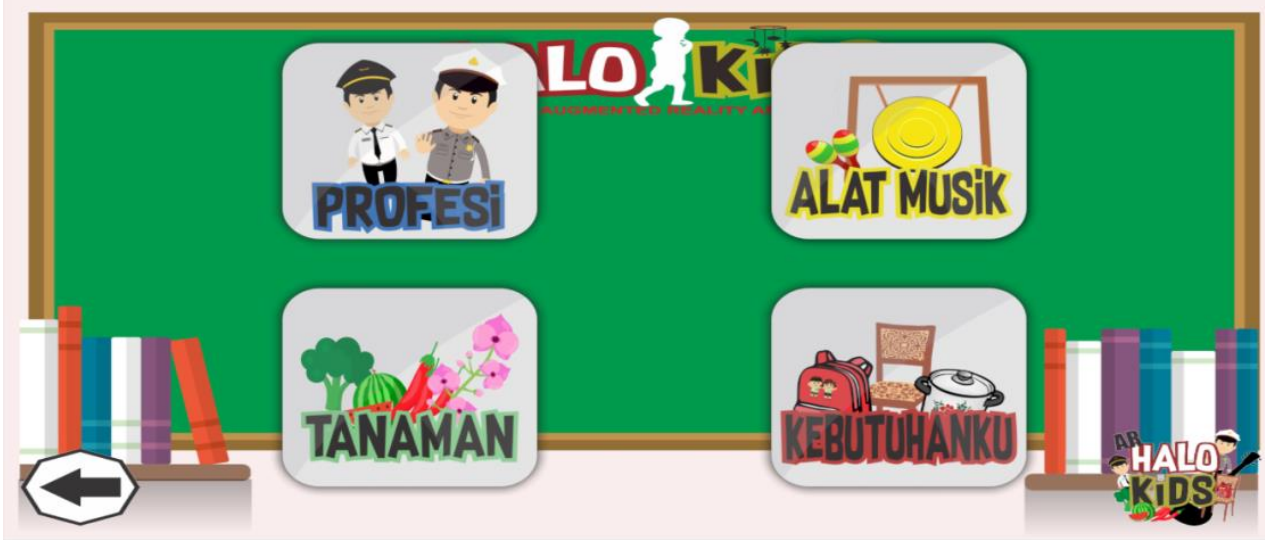

Gambar 8. Tampilan Menu 2D Aplikasi AR HALO KIDS 


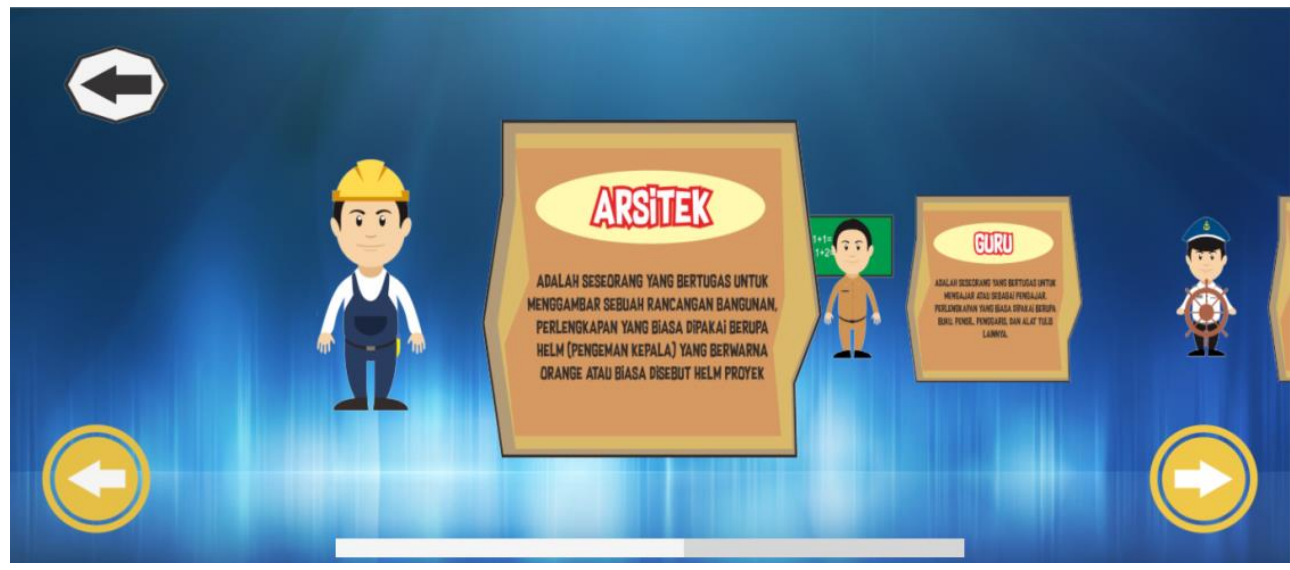

Gambar 9. Tampilan Konten 2D Aplikasi AR HALO KIDS

Tahap pengujian aplikasi AR HALO KIDS menggunakan metode blackbox testing. Metode blackbox testing adalah pengujian yang dilakukan hanya mengamati hasil eksekusi melalui data uji dan memeriksa fungsional dari perangkat lunak. Berikut ini adalah pengujian pada Aplikasi Augmented Reality Halo Kids yang disajikan ke dalam tabel-tabel pengujian sesuai fungsi-fungsi dalam aplikasi pada Tabel 2.

Tabel 3. 2 Blackbox Testing

\begin{tabular}{|c|c|c|c|c|}
\hline No & Jenis & Jenis & Tes & Keterangan \\
\hline \multirow[t]{8}{*}{1} & \multirow[t]{8}{*}{ Scene } & Splash screen & Sukses & Splash screen muncul \\
\hline & & & & $\begin{array}{l}\text { saat awal aplikasi } \\
\text { dijalankan }\end{array}$ \\
\hline & & Main Menu & Sukses & $\begin{array}{l}\text { Muncul setelah splash } \\
\text { screen }\end{array}$ \\
\hline & & Panduan & Sukses & $\begin{array}{l}\text { Muncul setelah tombol } \\
\text { Panduan ditekan }\end{array}$ \\
\hline & & Tentang & Sukses & $\begin{array}{l}\text { Muncul setelah tombol } \\
\text { Tentang ditekan }\end{array}$ \\
\hline & & Game Play & Sukses & Muncul setelah tombol \\
\hline & & Kebuhanku & & $\begin{array}{l}\text { game play } \\
\text { kebutuhanku ditekan }\end{array}$ \\
\hline & & $2 \mathrm{D}$ & Sukses & $\begin{array}{l}\text { Muncul setelah tombol } \\
\text { 2D ditekan }\end{array}$ \\
\hline
\end{tabular}

\begin{tabular}{llllll}
\hline 3 & $\begin{array}{l}\text { Sudut pandang } \\
\text { kamera ke marker }\end{array}$ & Semua & Objek & $0^{0}$ diatas marker & $\begin{array}{l}\text { Tiga kali percobaan } \\
\text { hasilnya terdeteksi }\end{array}$
\end{tabular}

(Jarak $30 \mathrm{~cm}$ dari marker) 


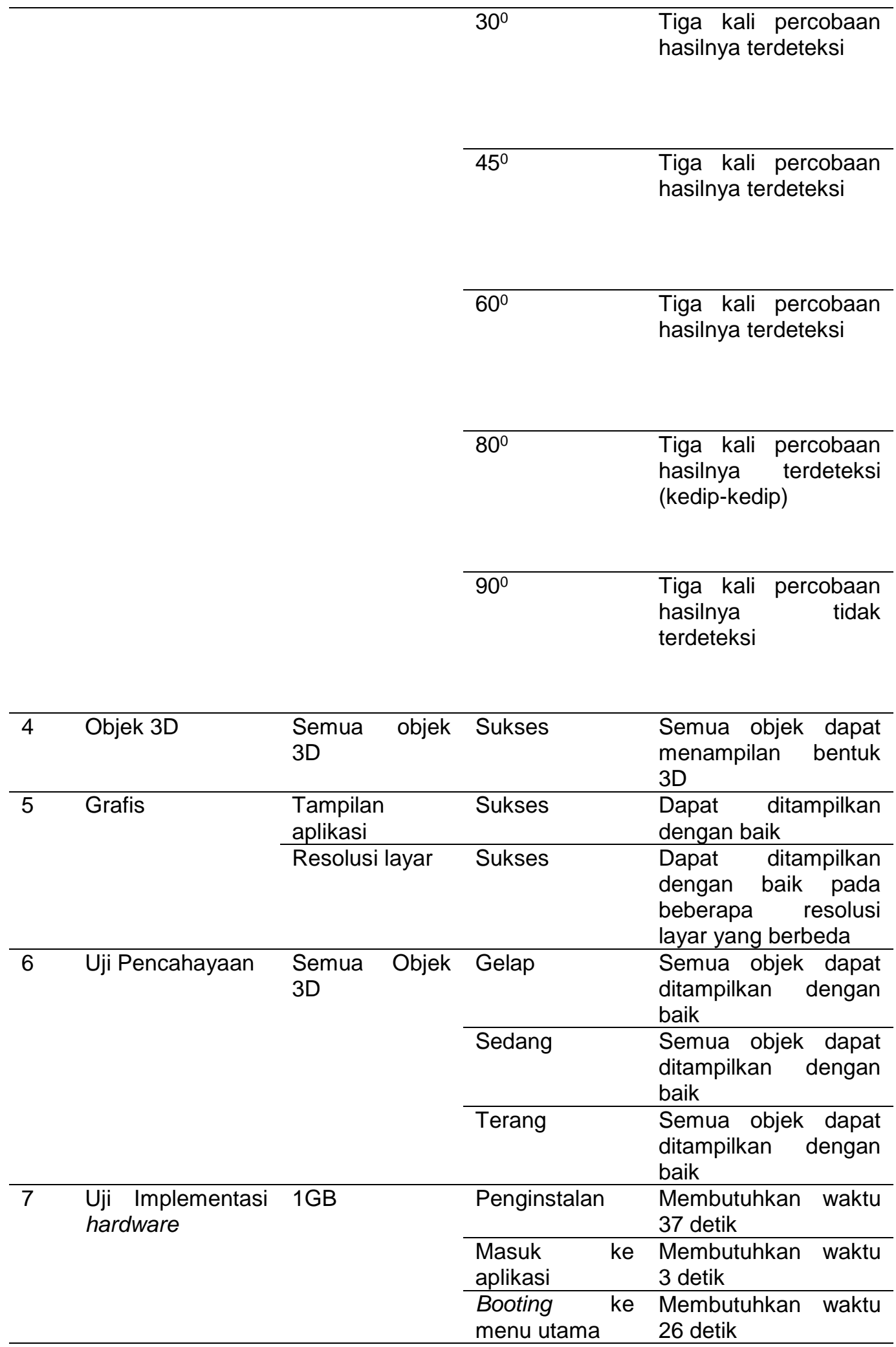




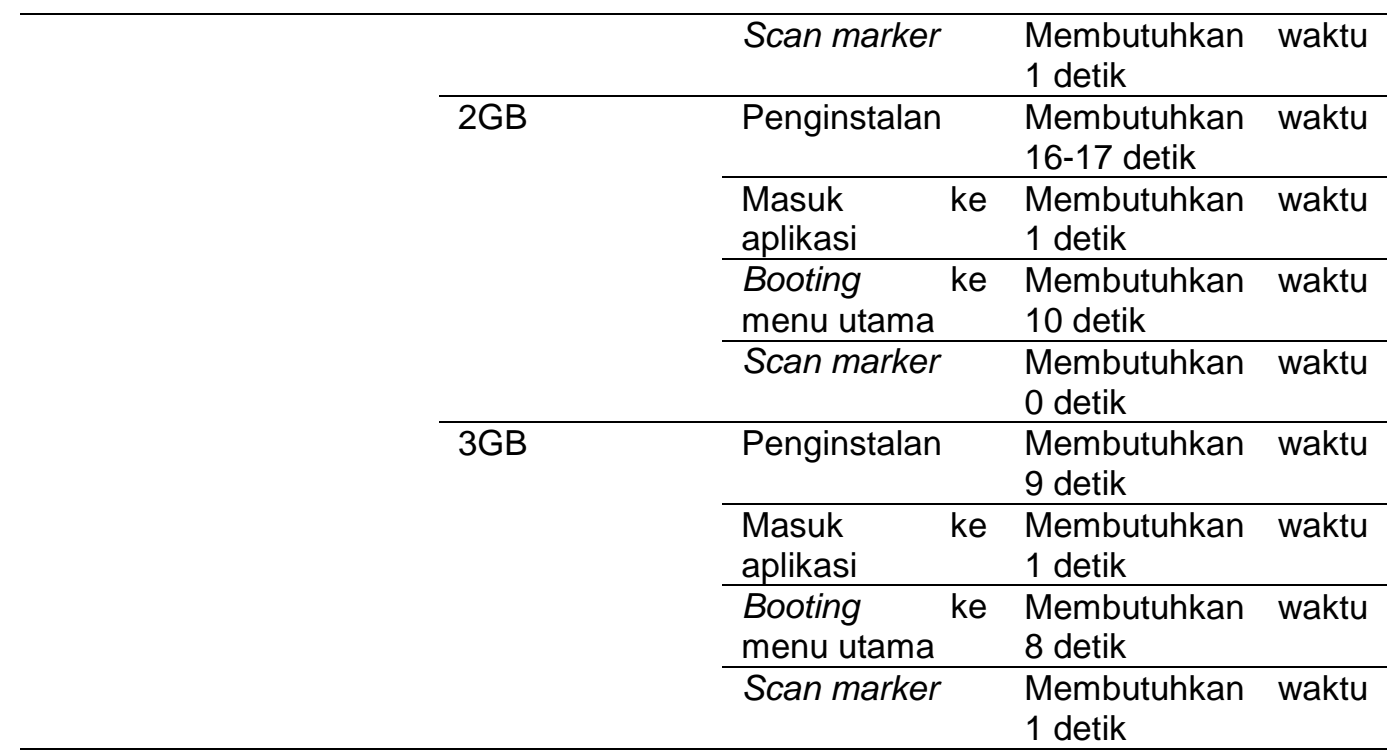

Pada evaluasi aplikasi didasarkan pada hasil pengujian. Aplikasi ini dapat berjalan lancar. Untuk menggunakan aplikasi ini, jarak ideal kamera untuk mendeteksi marker adalah $10 \mathrm{~cm}$ sampai $30 \mathrm{~cm}$. Sudut ideal untuk mendeteksi marker adalah berkisar antara $0^{\circ}$ diatas marker sampai $70^{\circ}$. Aplikasi HALO KIDS mampu membaca marker apabila cahaya kurang baik atau agak gelap.

Pengujian kemanfaatan aplikasi AR HALO KIDS juga dilakukan. Hasil kuisioner yang disajikan dalam bentuk presentase, data hasil penilaian diperoleh melalui penyebaran kuisioner kepada anak didik yang didampingi wali dan dibantu mahasiswa D3 Teknik Informatika berjumlah 12 yang telah diberi peraga aplikasi AR HALO KIDS dan marker yang disertakan untuk digunakan sebagai media ajar pengenalan materi kepada anak. Hasil penilaian aplikasi dari berbagai aspek penilaian disajikan pada Gambar 3.10 dan situasi saat pengujian disajikan pada Gambar 11.

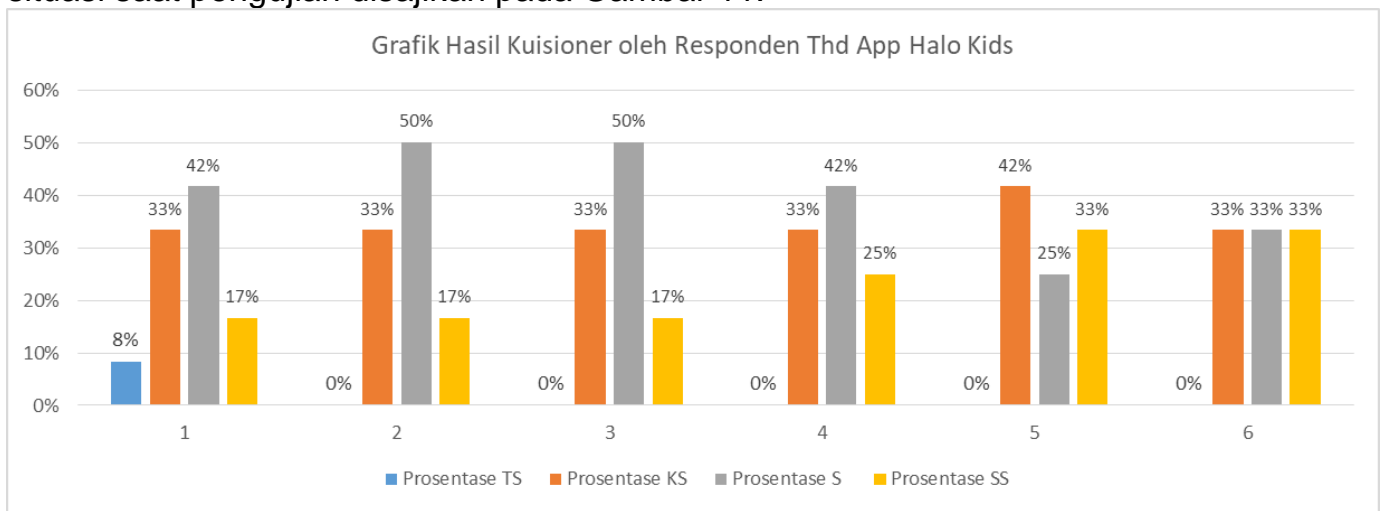

Gambar 10. Grafik hasil penilaian angket kuisioner oleh responden

Keterangan indeks:

$1=$ Kemudahan penggunaan $(S+S S=59 \%)$

$2=$ Kebaikan model $/$ karakter objek $(\mathrm{S}+\mathrm{SS}=67 \%)$

$3=$ Kejelasan audio $(\mathrm{S}+\mathrm{SS}=67 \%)$ 
$4=$ Kemudahan Navigasi (S+SS $=67 \%)$

$5=$ Ketertarikan anak (S+SS $=58 \%$ )

$6=$ Kemudahan mengingat oleh anak $(S+S S=67 \%)$

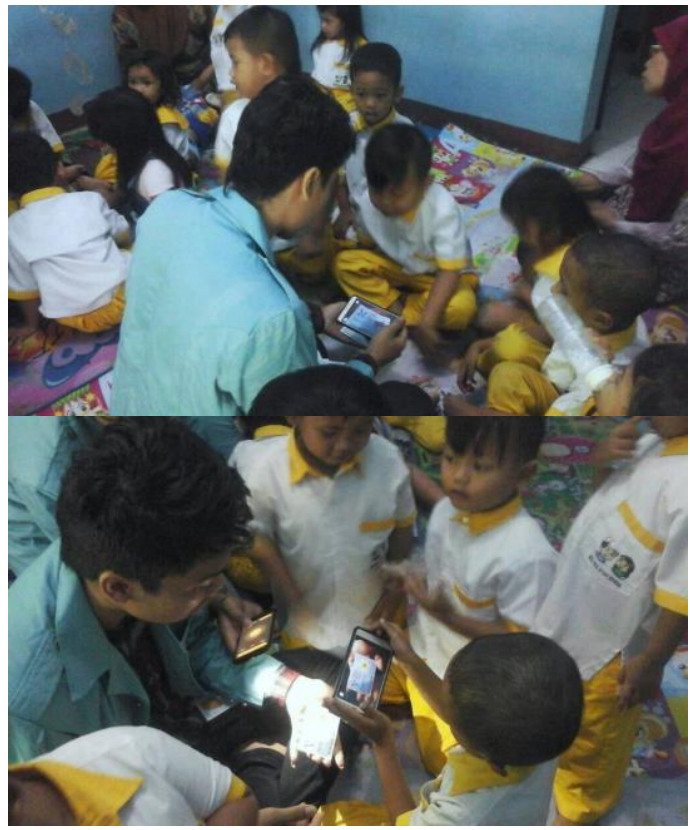

Gambar 11. Situasi pengujian aplikasi AR HALO KIDS di KB Ayah Bunda Colomadu

\section{KESIMPULAN}

Berdasarkan dari pembahasan diatas maka dapat ditarik kesimpulan bahwa Aplikasi AR HALO KIDS merupakan aplikasi dengan teknologi Augmented Reality berbasis Android. Konten aplikasi HALO KIDS ialah berupa gambaran visual 3D tentang beberapa tema diantaranya profesi, kebutuhanku, alat musik, dan Buah \& Sayur. Aplikasi HALO KIDS merupakan file dengan ekstensi .apk. Aplikasi HALO KIDS dijalankan secara optimal dengan ponsel pintar minimal berspesifikasi perangkat Quad-core 2.3 GHz (2 GB RAM). Pengguna aplikasi oleh anak-anak mudah untuk dilakukan dengan nilai Setuju-Sangat Setuju sebesar 59\%, objek 3D profesi dapat dikenali dan diingat oleh anak dengan nilai setuju-sangat setuju sebesar $67 \%$.

\section{DAFTAR PUSTAKA}

[1] Rincon M. Nubia; Garay R. Fabian; Rodriguez A. Wilson; Perez B. Wilmer. 2015. Development of a Mobile Application in Augmented Reality to Improve the Communication Field of Autistic Children at a Neurorehabilitar Clinic. IEEE:Workshop on Engineering Applications - International Congress on Engineering (WEA)

[2] Poonsri Vate-U-Lan, Ed.D, 2011. Augmented Reality 3D Pop-up Children Book:Instructional Design for Hybrid Learning. 5th IEEE International Conference on ELearning in Industrial Electronics (ICELIE). pp 95-100 
[3] Pedro Cunha, Jorge Brandão, José Vasconcelos. 2016. Augmented reality for cognitive and social skills improvement in children with ASD. 13th International Conference on Remote Engineering and Virtual Instrumentation (REV). pp 334-335

[4] Nur Afiqah Abu Bakar, Abdul Nasir Zulkifli, Nur Fadziana Faisal Mohamed. 2011. The Use of Multimedia, Augmented Reality (AR) and Virtual Environment (VE) in Enhancing Children's Understanding of Road Safety. IEEE Conference on Open Systems (ICOS2011), pp149-154

[5] Sukma, 2015. AR Mengenal Profesi Pekerjaan. Playstore.

tersedian online akses 4 januari 2017 URL :

https://play.google.com/store/apps/details?id=com.ARPengenalanPekerjaan.app\&hl= en 